\title{
Acute Respiratory Infection by Chlamydophila pneumoniae and Mycoplasma pneumoniae in a Population of Older Adults in Colombia
}

\section{Infección respiratoria aguda por Chlamydophila pneumoniae y Mycoplasma pneumoniae en una población de adultos mayores en Colombia}

Nidi L. Corredor-Cubides

Pontificia Universidad Javeriana, Colombia

Karent J. Beltrán-SuÁrez

Pontificia Universidad Javeriana, Colombia

JuAn Camilo Segura

Pontificia Universidad Javeriana, Colombia

LAURA BetTIN

Pontificia Universidad Javeriana, Colombia

JeAnette Coriat

Pontificia Universidad Javeriana, Colombia

Pilar R. Vargas

Pontificia Universidad Javeriana, Colombia

María J. Silva-Valencia

Pontificia Universidad Javeriana, Colombia

Lilia P. Guiza-Forero

Pontificia Universidad Javeriana, Colombia

María F. Gutiérrez-Fernández

Pontificia Universidad Javeriana, Colombia

Marylin Hidalgo-Díaz

Pontificia Universidad Javeriana, Colombia

Hugo Díez-Ortegaa

Pontificia Universidad Javeriana, Colombia

a Autor de correspondencia. Correo electrónico: hugo.diez@javeriana.edu.co

How to cite: Corredor-Cubides NL, Beltrán-Suárez KJ, Segura JC, Bettin L, Coriat J, Vargas PR, SilvaValencia MJ, Guiza-Forero LP, Gutiérrez-Fernández MF, Hidalgo-Díaz M, Díez-Ortega H. Acute respiratory infection by Chlamydophila pneumoniae and Mycoplasma pneumoniae in a population of older adults in Colombia. Univ Med. 2017;58(4):xx-xx. doi: http: //dx.doi.org/10.11144/Javeriana.umed58-4.pneu

\section{ABSTRACT}

Introduction: Acute Respiratory Infection (ARI) is a heterogeneous group of viral and bacterial respiratory pathologies including Chlamydophila pneumoniae (CP) and Mycoplasma pneumoniae (MP) that are not routinely identified; these infections in the older adults have mortality rates 3 to 5 times higher than that recorded in other age groups. Methods: this study was conducted prospectively to determine the proportion of atypical bacterial pathogens in older adults with ARI in Bogotá. Microbiological diagnosis was determined by real-time PCR (qPCR) in samples of respiratory origin and serology for antibodies IgG, IgA and IgM to MP and CP. Results: A total of 71 patients were enrolled from 2012 to 2013. Upper respiratory infections were diagnosed in the 
$69 \%$ of patients and lower respiratory infections in $31 \%$. MP was identified in $9.8 \%$ and CP in $8.5 \%$. Conclusions: these findings indicated that CP and MP must be viewed as a significant etiological agent of ARI in older adults in Bogotá.

Keywords

Mycoplasma pneumoniae; Chlamydophila pneumoniae; older adult.

\section{RESUMEN}

Introducción: La infección respiratoria aguda (IRA) es un grupo heterogéneo de patologías respiratorias de etiología viral y bacteriana que incluye Chlamydophila pneumoniae (CP) y Mycoplasma pneumoniae (MP), que no son identificados de manera rutinaria, y en el adulto mayor presentan tasas de mortalidad 3-5 veces mayores que las registradas en otros grupos etarios. Metodología: Estudio prospectivo para determinar la proporción de patógenos bacterianos atípicos en los adultos mayores con IRA, en Bogotá. El diagnóstico microbiológico se determinó mediante PCR en tiempo real (qPCR) en muestras de origen respiratorio y serología para anticuerpos IgG, IgA e IgM frente a MP y CP. Resultados: Un total de 71 pacientes fueron incluidos entre 2012 y 2013. Las infecciones respiratorias superiores fueron diagnosticadas en el $69 \%$ de los pacientes y las infecciones del tracto respiratorio inferior en un $31 \%$. MP fue identificado en el 9,8\% y el 8,5\% en CP. Conclusiones: Estos resultados indican que CP y MP son agentes etiológicos importantes de infecciones respiratorias agudas en los adultos mayores en Bogotá.

Palabras clave

Mycoplasma pneumoniae; Chlamydophila pneumoniae; adulto mayor.

\section{Introduction}

Acute respiratory infection (ARI) includes a heterogeneous group of infections compromising one or more parts of the respiratory system, and clinically they have an evolution period of less than 15 days. The ARI includes upper respiratory tract infections (URTI) and lower respiratory tract infections (LRTI), a term that includes a number of inflammatory pathologies called according to the affected site such as rhinosinusitis, otitis, mastoiditis, pharyngitis, tonsillitis, bronchitis, pneumonia, common cold, among others $[1,2,3]$. According to the report of the Forum of International Respiratory Societies 2013, respiratory tract infections are the leading cause of mortality, causing 4 million of deaths per year in developed countries [4].
In United States, ARI is the leading cause of outpatient visits and prescription of antibiotics in adults, where their misuse is a causal factor of bacterial resistance, alarming phenomena today given the increased morbidity and mortality as well as the high costs associated [4]. According to the 2015 National Study of Health, welfare and aging in Bogotá, the notification of ARI cases from the emergency department, outpatients, hospitalization in general ward and in intensive care unir, showed a slight decrease with respect to the previous two years. However, the prevalence of this disease is higher in children under 5 years, people with some chronic underlying disease, immunosuppression and people over 60 years old [5].

The estimate of the Colombian older people population aged between 60 and 80 years, is around 5.2 million in an overall population of 47 million. In Bogota\#, there were more than 7.5 million inhabitants, of which $11 \%$ were persons aged 60 years and older [5]. ARI incidence increases progressively with age, being pneumonia, particularly, the main cause of disease and death in the older adult and elderly. Infection in this group is characterized by a prolonged hospitalization and higher rates of risk and mortality compared to younger age groups; that can be explained by a gradual decrease in the integrity of the physical and immunological barrier against pathogens and by the variety of comorbid conditions presented in this age group $[5,6]$.

The etiology of ARI involves among other microorganisms the Streptococcus pneumoniae, Haemophilus influenza, Klebsiella pneumoniae, Staphylococcus aureus, and viruses such as Syncitial Respiratory Virus, influenza a and b, parainfluenza 1, 2 and 3, adenovirus, and atypical germs such as Chlamydophila pneumoniae (CP) and Mycoplasma pneumoniae (MP) $[7,8,9,10]$. Detection of atypical bacteria is a difficult process as they require for their diagnosis specialized techniques underused in our environment, also, there is a lack of golden tests, few commercial tests are available, and there is a lack of standardized approaches and appropriate validations for diagnostic techniques, reasons 
why there is diagnostics underreporting in Colombia $[8,11]$.

$\mathrm{MP}$ and CP can cause severe disease in older adults consequently causing hospitalization and even death. Infection in the older adults and elderly is characterized because the hospitalization is 4 to 6 times longer than in younger populations, with risk rates around $25-30 \%$ and mortality rate $3-5$ times higher than in young adults [6, 12]. Older adults often present comorbid medical conditions that favor the development of infection, sepsis and/or respiratory failure. Co-infection with other microorganisms is common and favors the development of complications. Atypical bacteria do not respond to monotherapy with b-lactam antibiotics, and additional coverage with macrolides persists as an optional therapy nowadays [13].

To contribute to the reduction of morbidity and mortality associated with atypical organisms causing ARI is necessary to perform an early and timely diagnosis to be able to choose the right treatment. In Colombia there are no unified and consistent criteria for the identification of atypical pathogens that can cause ARI, for their diagnosis, risk classification and treatment selection in older adults population. That is why it is considered pertinent to identify and determine the prevalence in our environment of M. pneumoniae and C. pneumoniae causing ARI in adults over 65 years.

\section{Methods}

\section{Setting, design and study population}

Observational, descriptive and cross-sectional study performed in adults over 65 years from a geriatric consultation centre consisting of four points of attention and care; they attended various medical services and were clinically defined by an specialist as a suspected and/or probable ARI case according to the guidelines proposed by Lieberman [14] and Woodhead [15]. It was considered as a suspicious case to all patients with an onset of clinical symptoms of less than 15 days with at least one major criteria (axillary $\mathrm{T}^{\circ} \geq 37.8{ }^{\circ} \mathrm{C}$, cough, mucopurulent sputum, tachypnea) and two minor ARI criteria (dyspnea, lethargy, convulsions, ventilatory failure, altered mental status, lung consolidation to auscultation, pleurisy, leukocytosis higher than $\left.12,000 / \mathrm{mm}^{3}\right)$. It was defined as a probable case of LRTI, if there was previous radiological evidence and cracking rales, reduced breath sounds or an area of bronchial breathing [14, 15].The study did not include patients that were in antimicrobial treatment with macrolides and broad spectrum antibiotics within 72 hours prior to the study and patients who were considered immunocompromised by clinical manifestations or by laboratory tests were excluded.

\section{Patient population}

The sample size was calculated with the program Sample size 1.0 and with the formula of "Point estimate of prevalence," taking into account the following factors: Type I error $=5 \%$; expected prevalence in the population $=12 \%$; maximum difference expected $=5 \%$; base population size $=100$ older adults [7]. The calculation set a minimum of 62 subjects and given that the sampling was done by convenience and multistage 5-6 patients a month were taken during 1 year. In the epidemiological profile identification data were tabulated, socioeconomic factors, environmental factors, dietary risk factors, factors associated with medical care, physical findings and paraclinical findings.

\section{Specimen collection}

Samples of respiratory origin were taken from each patient according to the pathology at consultation (sputum, nasopharyngeal sample or a swab of the back of the throat), to identify microorganisms by real-time PCR (qPCR) as well as serum samples to titrate $\mathrm{ABS} \operatorname{IgM}$, IgG and IgA against MP and CP. 
qPCR

For molecular identification of CP and MP, bacterial DNA was initially extracted with the commercial Kit QIAamp DNA and Blood Mini Kit QIAGEN following the manufacturer's instructions and from this a qPCR was performed using the diagnostic kits In Vitro Liferiver (TM): Mycoplasma pneumoniae Real Time PCR kit RD-0100-02 and Chlamydophila pneumoniae Real Time PCR kit RD-0099-02.

\section{Serological diagnosis}

In order to correlate the presence of CP and $\mathrm{MP}$ with the patient's clinical symptoms and patient's seroconversion, an ELISA test IgA, IgG and IgM was performed simultaneously with the commercial diagnostic Kit by NovaTec Inmundiagnostica GMBH MYCA0350 for MP and Dia.Pro Diagnostic Bioprobes CPA-EC for CP.

Evaluation and clinical interpretation of antibody titers against CP was based on the methodology used by Paldanius and cols. [16] and Chedid and cols. [17] based on the analysis of the kinetics of the isotypes of Immunoglobulins tested, clinical evidence of respiratory infection versus antibody titer and the cutoffs points established by the commercial kit where IgM titers $>1: 10$ and $\operatorname{IgA}$ titers $>1: 16$ with obvious respiratory symptoms are indicative of recent infection and should be considered as positive; low titers IgG with positive IgM or positive IgA is set to be confirmed by paired titration in acute phase and convalescent phase, considering suggestive of acute infection an increment of 4 times in the titer of $\operatorname{IgG}$ and/or IgA between consecutive serums.

The evaluation and interpretation of ABS for MP was based on the cutoff points set by the commercial kit in conjunction with the clinical evaluation of the patient and the guidelines proposed by Csango and cols. [18] and Barbeyrac and cols. [19]. Those IgM and IgA results that were consistent with acute infection were considered positive, and negative results were confirmed with a second sample at 21 days.

\section{Results}

\section{Patient characteristics}

More than the minimum number established for calculation of sample was collected. That is how 71 subjects who met the inclusion criteria were included. Of these, 56.3\% (40/71) were male and $43.7 \%(31 / 71)$ were females, with an average age of 76 years and 72 years respectively, ranging from 65 to 95 years. One of the most common physical findings was chest indrawing by $67 \%$ (48/71), followed by cough $52.1 \%$ (37/71), sputum $28.2 \%$ (20/71), tachypnea 26.8\% (19/71) and cyanosis in $8.5 \%(6 / 71)$, distributed according to the type of respiratory infection.

\section{Clinical evolution and outcomes}

Of the 71 patients studied, 69\% (49/71) showed URTI of which $33.8 \%$ (24/71) presented common cold, $15.5 \%$ (11/71) pharyngitis, $9.9 \%$ (7/71) sinusitis, 5.6\% (4/71) laryngitis and 4.2\% (3/71) tonsillitis. $31 \%(22 / 71)$ of the subjects had LRTI with prevalence of pneumonia $23.9 \%$ $(17 / 71)$ and bronchitis 7\% (5/71).

\section{Serology for Chlamydophila pneumoniae}

The obtained results showed 62\% (44/71) of negative results and the presence of $\mathrm{ABS}$ against $\mathrm{CP}$ in $38 \%$ of patients $(27 / 71)$. Of the 27 patients, $32.4 \%(23 / 71)$ were reactive for $\mathrm{IgG}$ without significant increment of titers in the second sample, $5.6 \%(4 / 71)$ were clinically acute infections with 1 positive case of IgA, 1 positive case of IgM and 2 cases presented both IgM and $\operatorname{Ig} \mathrm{A}$. 
Serology for Mycoplasma pneumonia

The results obtained for each of the ABS evaluated showed that $66.2 \%(47 / 71)$ were negative and $33.8 \%(24 / 71)$ of the individuals presented reactivity to at least one $A B$ isotype. Of the 24 reactive individuals, $25.3 \%(18 / 71)$ showed no reactivity for IgG and subsequent seroconversion was not observed in paired serum, $8.4 \%(6 / 71)$ had acute infection of which 4 were positive for IgA and 2 were positive for IgM and IgA simultaneously.

\section{Molecular identification of Chlamydophila} pneumoniae and Mycoplasma pneumoniae

qPCR results showed the presence of $\mathrm{CP}$ in $8.5 \%(6 / 71)$, which included 4 cases previously detected by serology and 2 cases of patients who were seronegative for $\operatorname{IgA}$ and IgM. MP was detected in $9.9 \%(7 / 71)$ which included the 6 cases that were positive for $\operatorname{IgM}$ and $\operatorname{IgA}$ and 1 new case that had not presented reactivity for IgA/IgM with ELISA.

\section{ARI associated with atypical pathogens}

The study data showed that it was possible to isolate the etiologic agent in 41 individuals (57.7\%) of which $40.8 \%$ (29/71) corresponded to fast-growing bacteria and viruses, reported in a simultaneous study [7] and $18.3 \%$ (13/71) presented an atypical microorganism by molecular biology and titration of ABS IgA/IgM; 9.8\% (7/71) for MP and 8.5\% (6/71) for CP, objective of this study.

The presence of MP was associated to 2 cases for pneumonia, 2 for bronchitis and 3 for pharyngitis, while CP appeared in 1 case for pneumonia, 1 of bronchitis, 1 of pharyngitis and 1 of sinusitis. Mixed infections were observed in the case of the patient with pneumonia, where MP and CP were simultaneously identified; a second patient presented a case of pneumonia between one typical bacterium such as $K$. pneumoniae (Kpn) and an atypical as MP.

\section{Discussion}

In Colombia, ARIs are the fifth leading cause of death in adults older than 60 years and its impact is reflected in the high number of hospitalizations, disability of the affected population, the high degree of morbidity and mortality, the cost in the care of them and the low number of studies in the area for this age group [20]. Nationwide reports on ARI, correspond to specific studies focused on community-acquired pneumonia involving different age groups, being the most recent the studies by Caballero et al. [21]; Montúfar et al. [22]; Robledo et al. [23]; Vélez et al. [24], or correspond to research related to specific microorganisms as case studies and mortality by infection with H1N1 such as the studies from Porras et al. [25] and Rey et al. [26].

In that sense, this study provides important data, showing that from $57.7 \%$ of the isolates $18.3 \%$ were atypical organisms such as CP and $\mathrm{MP}$, very significant percentage of the elderly population because these microorganisms are not identified routinely in hospitals and in some cases they might be diagnosed as viral infections being prescribed a wrong treatment.

Among the ARIs, it was found that 69\% presented URTI, 31\% presented LRTI, the cough was one of the most common physical findings $(52.1 \%)$ and common cold was the most representative pathology in URTI (33.8\%) and pneumonia in LRTI (23.9\%). The data obtained are similar to those reported by other researchers in populations of older adults like Wójkowska et al. [27] showing a higher percentage of ARIURTI; Choy et al. [28], who show the common cold as the respiratory condition that affects the most the geriatric population; Evertsen et al. [29] establishing cough as a criteria of a high predictive value in ARI and pneumonia in different studies present percentages ranging from $20 \%$ to $66 \%$ inclusive $[30,31]$. The data in this age population are explained by the presence of multifactorial causes that include physiological and immune changes according to the age, immunosenescence, pulmonary changes such as mucociliary clearance and decreased protective reflexes such as cough, increased 
lung compliance, decreased number of alveolar macrophages and neutrophils, the presence of concomitant diseases such as COPD and the institutionalization in geriatric units among others $[6,32,33,34]$.

Although technological advances allow us to identify a large percentage of etiologic agents of ARI, there are still shortcomings in the identification of MP and $\mathrm{CP}$ and there are limitations for the proper interpretation of serological and molecular tests and their correlation to the patient's clinical symptoms [11, 32]. However, guidelines proposed by Csango et al. [18]; Paldanius et al. [16]; Chedid et al. [17], and Barbeyrac et al. [19], keep a good correlation with the clinical findings in the patients, and these guidelines were applied in the present study. Serological results for CP showed IgG reactivity of $32.4 \%, 2.8 \% \operatorname{IgM}$, and $2.8 \% \operatorname{IgA}$. IgG titers have been documented by different authors, who suggest that the prevalence increases with age, reaching $50 \%$ of reactivity in young adults and can reach up to $75 \%$ of reactivity in older adults and the elderly [35]. The importance of the $\mathrm{IgG}$ reactivity found in the study suggests that people have subclinical infections by $\mathrm{CP}$ or get reinfected throughout life, highlighting the problem of underdiagnosis and lack of epidemiological data on the infection [35]. In terms of IgM it is known that titers appear during the first 3 weeks and are replaced by IgG from the $6^{\text {th }}$ to $8^{\text {th }}$ week, meanwhile, in reinfection IgM is detectable in the first 2 weeks, disappears between 4 to 6 months and leads the IgG from week 1 or 2 and can last up to 3 years. To determine the pattern of infection this kinetic requires to take a second serum sample in the convalescence period or to verify the persistence of IgA or the detected Ag through molecular tests [36]. These guidelines were contemplated in the study and that is how the results could be verified with IgA; also, through qPCR two new cases that had not presented serologic reactivity, due to a higher sensitivity of the molecular technique [37], were found.

Regarding MP, it was observed that $8.4 \%$ of individuals had litres of IgA and IgM clinically associated with respiratory infection. Infections caused by MP are characterized by a slow rise of specific IgG reaching the highest values at 5 weeks after the start of symptomatology. After the infection, these antibodies remain elevated for periods of up to 4 years. Therefore, low levels may indicate past infection or early stages of acute infection. In this case a second sample should be analyzed at 2 or 3 weeks to demonstrate an increase in the antibodies titer and the diagnosis requires the quadrupling of the values or titers greater than or equal to $1 / 32$ [38]. While infections by MP are common in children and young adults under 19 years and are detected in low percentages in older adults, in this age group morbidity and mortality are usually higher $[6,12,39]$, reason why $8.4 \%$ of detected cases in this study is significant, since knowing the physiopathology, clinical and etiology of the infection by atypical microorganisms helps us improve the diagnosis, treatment and prevention of acquired pneumonia in immunocompetent adults, as established by the Colombian Association of Infectious Diseases (ACIN) [40] in its guide of clinical practice from 2013 and the institutional guidelines proposed by Forero [41]. Although serological techniques have sensitivity and specificity greater than $90 \%$, diagnosis can be improved in its efficiency by molecular techniques. That is how Kumar and Hammerschlag [42] proposes that diagnosis of CP should include ELISA and a molecular technique such as PCR, while Waites and Talkington [43] proposes that PCR should be the test of choice for MP. This study showed that the percentage of positive cases by serology increased when molecular techniques were used. CP went from $5.6 \%$ to $8.5 \%$ and in MP from $8.4 \%$ to $9.9 \%$. In Colombia, different authors like Robledo et al. [23], Velez et al. [24], Montufar et al. [44], and others mentioned in the guide of clinical practice from 2013 from the ACIN [40], have reported different etiologic agents associated with ARI allowing to spread the knowledge on the epidemiology of infection in some parts of the country. However, the use of molecular techniques has changed some of the epidemiological and clinical concepts on CP and MP due to the sensitivity of the 
techniques. For this reason, it is recommended that the persistence of $\mathrm{MP}$ or $\mathrm{CP}$ in respiratory samples require studies to standardize and define the number of copies/mL that allow the differentiation of clinical infection from residual colonization [37]. In this regard, this study used as a molecular technique a qPCR that allowed obtaining such data.

Finally, it should be emphasized the mixed infections that occurred between MP and CP, as well as MP and Kpn. Such infections have been reported in some studies and are attributable to superinfections, predisposing factors such as asthma, increasing hypersensibility to one of the infections or to behaviors that MP may have as commensal flora in immunocompetent patients [45], which is important to keep in mind when interpreting the results as well as when doing the processes of therapeutic intervention in the patient.

\section{Conclusion}

The work generated new knowledge on the behavior of the two microorganisms in older adults, allowing to determine that the majority of the population have immunological contact with these two microorganisms at some point; $\mathrm{CP}$ and MP are important etiological agents of ARI in older adults who present more aggressive clinical symptoms and the use of quantifying molecular techniques such as qPCR is important to detect microorganisms difficult to diagnose as those mentioned in the article.

\section{Acknowledgements}

To the Pontificia Universidad Javeriana for financing the project and to health centers GH\&M Ltda. and Clinical Laboratory Country Center for their support in its execution.

\section{References}

1. Valero N, Larreal Y, Arocha F, Gotera, J, Mavarez A, Bermudez J, et al. Viral etiology of acute respiratory infections. Invest Clin. 2009;50(3):359-68.

2. Drummond P, Clark J, Wheelar J, Galloway A, Freeman $\mathrm{R}$, Cant A. Community acquired pneumonia a prospective UK study. Arch Dis Child. 2005;83:408-12.

3. Harris A, Hicks LA, Qaseem A. Appropriate antibiotic use for acute respiratory tract infection in adults: Advice for highvalue care from the American College of Physicians and the Centers for Disease Control and Prevention. Ann Intern Med. 2016;164(6):425-35.

4. Ferkol T, Schraufnagel D. The global burden of respiratory disease. Ann Am Thorac Soc. 2014;11(3):404-6.

5. Malo D, Pulido P, Barbosa J. Vigilancia y análisis del riesgo en salud pu\#blica: Protocolo de Vigilancia en Salud Pu\#blica Infección Respiratoria Aguda (IRA). Bogotá: Instituto Nacional de Salud; 2016.

6. Meyer KC. The role of immunity and inflammation in lung senescence and susceptibility to infection in the elderly. Semin Respir Crit Care Med. 2010;31(5):561-74.

7. Beltrán K, Segura JC, Bettin L, Coriat J, Mercado M, Hidalgo M, Díez H. Etiología viral de las infecciones respiratorias agudas (IRA) en adultos mayores procedentes de una unidad de cuidado geriátrico. Ciencia Actual. 2015;5:10-8.

8. Álvarez FA. Neumonías adquiridas en la comunidad en pacientes mayores de 65 años: incidencia de gérmenes atípicos y evolución clinicorradiológica. Med Clin Barc. 2001;117(12):41-5.

9. Gillén R, Franco R, Franco L, Moraga P, Ojeda M, Russomando G. Multiplex PCR for detection of atypical bacteria in community acquired pneumonia patients attending INERAM hospital. Mem Inst Investig Cienc Salud. 2012;1:24-35.

10. Posfay-Barbe KM. Infections in pediatrics: Old and new diseases. Swiss Med Wkly. 2012;142:w13654.

11. Villegas E, Solórzano A, Gutiérrez J. Serological diagnosis of Chlamydophila 
Nidi L. Corredor-Cubides, Karent J. Beltrán-Suárez, Juan Camilo Segura et al.

pneumoniae infection: Limitations and perspectives. J Med Microbiol. 2010;59:1267-74.

12. Saldías F, Mardónez JM, Marchesse M, Viviani P, Farías G, Díaz A. Neumonía adquirida en la comunidad en el adulto hospitalizado: cuadro clínico y factores pronósticos. Rev Méd Chile. 2002;130:1373-82.

13. Lui G, IP M, Lee N, Rainer TH, Man S, Cockram C y col. Role of 'atypical pathogens' among adult hospitalized patients with community-acquired pneumonia. Respirology. 2009;14:1098-1105.

14. Lieberman D, Lieberman D. Management of respiratory infections in the elderly. Expert Rev Anti Infect Ther. 2003;1(3):505-16.

15. Woodhead M, Blasi F, Ewig S, Garau J, Huchon G, Ieven M, et al. Guidelines for the management of adult lower respiratory tract infections - summary. Clin Microbiol Infect. 2011;17(6):1-24.

16. Paldanius M, Bloigu A, Alho M, Leinonem M, Saikku P. Prevalence and persistence of Chlamydia pneumoniae antibodies in healthy laboratory personnel in Finland. Clin Diagn Labo Immunol. 2005;12(5):654-9.

17. Chedid MB, Chedid MF, Ilha DO, Bozzetti M, Chaves L, Griza D, Dalcin P. Community-acquired pneumonia by Chlamydophila pneumoniae: a clinical and incidence study in Brazil. Braz J Infect Dis. 2007;11(1):75-82.

18. Csango PA, Pedersen JE, Hess RD. Comparison of four Mycoplasma pneumoniae IgM, IgG and IgA-specific enzyme immunoassays in blood donors and patients. Clin Microbiol Infect. 2004;10:1094-8.

19. Barbeyrac B, Obeniche F, Ratsima E, Labrouche S, Morate\# C, Renaudin H, et al. Limites et perspectives du diagnostic se\# rologique a\# l'e\# re de l'amplification ge\#nique in vitro: infections ge\#nitales a\# Chlamydia trachomatis et infections respiratoires a\# Chlamydia pneumoniae et
Mycoplasma pneumoniae. Ann Biol Clin. 2006;64(5):409-19.

20. Ministerio de Salud y Protección Social de Colombia. Indicadores básicos situación de salud en Colombia: IRA adultos [internet]. Disponible en http://www.minsalud.gov.co/salud/.../IN DICADORESBASICOSSP.aspx

21. Caballero A, Polanía E, Gordillo M, Martínez O, Torrado E, Lagos M, et al. Agentes etiológicos de la neumonía adquirida en la comunidad (NAC) en pacientes adultos inmunocompetentes que consultan al servicio de urgencias de la clínica Reina Sofía. Bogotá, 2006-2007. Rev Medica Sanitas. 2010;13(2):8-18.

22 .Montu\#far FE, Correa LT, Rueda ZV, Ortega H, Ortega J, Segura A, et al. Neumoni\#a severa adquirida en comunidad: caracteri\#sticas cli\#nicas y resultados de la atencio\#n intrahospitalaria. Estudio multicentrico en el Valle de Aburra\#. Infectio. 2006;10:103.

23. Robledo J, Sierra P, Bedoya F, London\#o A, Porras A, Luja\#n M, et al. Neumoni\#as adquiridas en la comunidad en adultos: un estudio etiolo\#gico prospectivo con e\#nfasis en el diagno\#stico. Rev Colomb Neumol. 2003;15:7-14.

24. Ve\#lez L, Rueda Z, Aguilar Y, Rojas E, Arroyave M, Segura A, et al. NAC en Medelli\#n, 2005-2006: alta frecuencia de bacterias ati\# picas y virus respiratorios. Rev Colomb Neumol. 2007;19:154.

25. Porras A, Rico A, Moreno J, Cótes K, López J, Herrera D, et al. Mortality associated with peak seasons of influenza virus circulation in Bogota, Colombia, 1997-2005. Rev Panam Salud Pública. 2009;26(5):435-9.

26. Rey G, Castro M, Castillo JO. Descriptive analysis of the first deaths for pandemic influenza (H1N1) 2009 in Colombia. Infectio. 2009;3 (4):254-8.

27. Wójkowska J, Gryglewska B, Romaniszyn D, Natkaniec J, Pobiega M, Adamski P, et al. Age and other risk factors of pneumonia among residents of polish long-term care 
facilities. Int J Infect Dis. 2013;17(1):e37e43.

28. Choy C, Chen H, Yau C, Hsu E, Chik NY, Wonh A, et al. Prevalence of infections among residents of Residential Care Homes for the Elderly in Hong Kong. Hong King Med J. 2016;22(4):347-55.

29. Evertsen J, Baumgardner D, Regnery A, Banerjee I. Diagnosis and management of pneumonia and bronchitis in outpatient primary care practices. Prim Care Respir J. 2010;19(3):237-41.

30. Rojas D. Morbilidad y mortalidad del adulto mayor en un servicio de medicina de un hospital general del Perú. Rev Peruana Epidemiol. 2011;14(2):99-107.

31. Ahmed S, Jakribettu R, Meletath, S, Arya B, Shakir V. Lower respiratory tract infections (LTRIs): An insight into the prevalence and the antibiogram of the gram negative, respiratory, bacterial agents. J Clin Diagn Res. 2013;7(2):253-6.

32. Geffen L. Common upper respiratory tract problems in the elderly - A guide to clinical diagnosis and prudent prescription. S Afr Fam Pract. 2006;48(5):20-3.

33. Liang S, Mackowiak P. Infections in the elderly. Clin Geriatr Med. 2007;23(2):441-56.

34. Martínez N, Apezteguía I, Renedo J, Infante B. Respiratory tract infections. Rev Esp Geriatr Gerontol. 2007;42 (suppl 1):51-5.

35. Kuo C, Jackson L, Campbell L, Grayston T. Chlamydophilae pneumoniae (TWAR). Clin Microbiol Rev. 1995;8:451-61.

36. Dowell S, Peeling R, Boman J, et al. Standardizing Chlamydophila pneumonia assays: Recommendations from the centers for disease control and prevention (USA) and the laboratory center for disease control. Canada Clin Infec Dis. 2001;33:492-503.

37. Loens K, Beck T, Ursi D, Overdijk M, Sillekens P, Goossens $\mathrm{H}$, et al. Development of real-time multiplex nucleic acid sequence-based amplification for detection of Mycoplasma pneumoniae, Chlamydophila pneumoniae, and Legionella spp. in respiratory specimens. J Clin Microbiol. 2008;46(1):185-91.

38. Daxboeck F, Krause R, Wenisch C. Laboratory diagnosis of Mycoplasma pneumoniae infection. Clin Microbiol Infect. 2003;9:263-73.

39. Paúl D, Vega-Briceño, Potin L, Ferrés M, Pulgar M, García D, Holmgren D, Sánchez I. Características clínicas de la enfermedad respiratoria causada por Mycoplasma pneumoniae en niños hospitalizados. Rev Chil Infectol. 2009;26(4):343-9.

40. ACNCT, AMCI, ACMI, ACIN. Guía de práctica clínica: recomendaciones para el diagnóstico, tratamiento y prevención de la neumonía adquirida en la comunidad en adultos inmunocompetentes. Infectio. 2013;17(Supl 1):1-38.

41. Forero JC. Neumonía adquirida en comunidad en el adulto: es hora de implementar las guías de manejo clínico institucionales. Acta Med Colomb. 2013;38(4):206-7.

42. Kumar S, Hammerschlag M. Acute respiratory infection due to Chlamydia pneumoniae: Current status of diagnostic methods. Clin Infect Dis. 2007;44(4):568-76.

43. Waites KB, Talkington DF. Mycoplasma pneumoniae and its role as a human pathogen. Clin Microbiol Rev. 2004;17(4):697-728.

44. Montúfar FE, Rueda ZV, Correa LT, Ortega $\mathrm{H}$, Ortega J, Segura A, et al. Características y comportamiento de la Neumonía Adquirida en la Comunidad (NAC) en adultos mayores ( $\geq 6$ 65años) hospitalizados en el Valle de Aburrá, Antioquia, Colombia. Infectio. 2006;10:113.

45. Megías A, Gómez JA, Navarro M, Urán M, González MI, Rodríguez R. Coinfección por Chlamydia y Mycoplasma: incidencia en nuestro medio. An Pediatr. 2002;57(2):110-5. doi: 10.1016/ S1695-4033(02)78683-9 